Nephrology

\title{
Adhesion Molecules in Renal Disease
}

Guest Editor

Michael S. Goligorsky, Stony Brook, N.Y.

14 figures and 16 tables, 1999

KARGER 
S. Karger

Medical and Scientific Publishers Basel $\cdot$ Freiburg $\cdot$ Paris $\cdot$ London New York $\cdot$ New Delhi $\cdot$ Bangkok Singapore $\cdot$ Tokyo $\cdot$ Sydney
Drug Dosage

The authors and the publisher have exerted every effort to ensure that drug selection and dosage set forth in this text are in accord with current recommendations and practice at the time of publication. However, in view of ongoing research, changes in government regulations, and the constant flow of information relating to drug therapy and drug reactions, the reader is urged to check the package insert for each drug for any chang in indications and dosage and for added warnings and precautions. This is particularly important when the recommended agent is a new and/or infrequently employed drus.
All rights reserved.

No part of this publication may be translated into other languages, reproduced or utilized in any form or by any means, electronic or mechanical, including photocopying, recording, microcopying, or by any information storage and retrieval microcopying, or by any information storage and retrieval system, without permission in writing from the publisher or, in
the case of photocopying, direct payment of a specified fee to the case of photocopying, direct payment of a specified fee
the Copyright Clearance Center (see 'General Information').

(c) Copyright 1999 by S. Karger AG,

P.O. Box, CH-4009 Basel (Switzerland)

Printed in Switzerland on acid-free paper by

Reinhardt Druck, Basel

ISBN 3-8055-6886-X

\section{KARGER}

Fax+41613061234

E-Mail karger@karger.ch

www.karger.com 


\section{Nephrology}

79 Introduction

Goligorsky, M.S. (Stony Brook, N.Y.)

80 Cell Adhesion Molecules in the Kidney: From Embryo to Adult Perantoni, A.O. (Frederick, Md.)

103 Osteopontin Function in Pathology: Lessons from Osteopontin-Deficient Mice

Rittling, S.R.; Denhardt, D.T. (Piscataway, N.J.)

114 Cystic Diseases of the Kidney: Role of Adhesion Molecules in Normal and Abnormal Tubulogenesis

Wilson, P.D.; Burrow, C.R. (New York, N.Y.)

125 Leukocyte-Endothelial Cell Interactions: Lessons from Knockout Mice Rosenkranz, A.R.; Mayadas, T.N. (Boston, Mass.)

137 Mesangial Cells and Their Adhesive Properties Pröls, F.; Hartner, A.; Schöcklmann, H.O.; Sterzel, R.B. (Erlangen)

147 Mesangial Matrix Modulation and Glomerulosclerosis Fogo, A.B. (Nashville, Tenn.)

160 Glomerular Podocytes and Adhesive Interaction with Glomerular Basement Membrane

Mundel, P. (Bronx, N.Y.); Shankland, S.J. (Seattle, Wash.)

167 Progressive Renal Disease: Fibroblasts, Extracellular Matrix, and Integrins Norman, J.T.; Fine, L.G. (London)

178 Arg-Gly-Asp (RGD) Peptides and Peptidomimetics as Therapeutics: Relevance for Renal Diseases Horton, M.A. (London)

185 Diapedesis of Leukocytes: Antisense Oligonucleotides for Rescue Dragun, D.; Haller, H. (Berlin)

193 Use of Adhesion Molecules for Gene Delivery Hart, St. (London)

200 Author Index 200 Subject Index

\section{KARGER}

Fax+41613061234 E-Mail karger@karger.ch www.karger.com (c) 1999 S. Karger AG, Basel

Access to full text and tables of contents, including tentative ones for forthcoming issues: www.karger.com/journals/exn/exn_bk.htm 